\title{
DIRECTIONS HOME
}

\section{APPROACHES TO AFRICAN-CANADIAN LITERATURE}

The latest work from pioneering scholar George Elliott Clarke, Directions Home is the most comprehensive analysis of African-Canadian texts and writers to date. Building on the insights in his critically acclaimed Odysseys Home, Clarke passionately analyses the beautiful complexities and haunting conundrums of this important body of literature.

Directions Home explores the trajectories and tendencies of African-Canadian literature within the Canadian canon and the socio-cultural traditions of the African Diaspora. Clarke showcases the importance of little-known texts, including church histories and slave narratives, and offers studies of autobiography, crime and punishment, jazz poetics, and musical composition. The collection includes studies of significant contemporary writers such as George Boyd and Dionne Brand, as well as trailblazing African-Canadian intellectuals such as A.B. Walker and Anna Minerva Henderson.

With its national, regional, and historical perspectives, Directions Home is an essential guide to African-Canadian literature.

GEORGE ELLIOTT CLARKe is E.J. Pratt Professor of Canadian Literature at the University of Toronto. 
This page intentionally left blank 


\section{DIRECTIONS HOME}

APPROACHES TO AFRICAN-CANADIAN LITERATURE

GEORGE ELLIOTT CLARKE 
(C) University of Toronto Press 2012

Toronto Buffalo London

www.utppublishing.com

Printed in Canada

ISBN: 978-0-8020-9153-6 (cloth)

ISBN: $978-0-8020-9425-4$ (paper)

(6)

Printed on acid-free, Io०\% post-consumer recycled paper with vegetable-based inks

\section{LIBRARY AND ARCHIVES CANADA CATALOGUING IN PUBLICATION}

Clarke, George Elliott, I960-

Directions home : approaches to African-Canadian literature / George Elliott Clarke.

Includes bibliographical references and index.

ISBN 978-0-8020-9153-6 (bound) ISBN 978-0-8020-9425-4 (pbk.)

I. Canadian literature - Black Canadian authors - History and criticism. 2. Black

Canadians in literature. 3. Race in literature. I. Title.

PS8089.5.В5С55 $2012 \quad$ C810.9'89607I C20I2-90222I-7

University of Toronto Press acknowledges the financial assistance to its publishing program of the Canada Council for the Arts and the Ontario Arts Council.

\section{Canada Council \\ Conseil des Arts

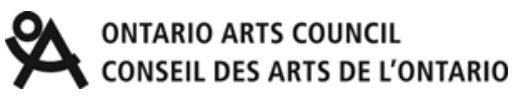

This book has been published with the help of a grant from the Canadian Federation for the Humanities and Social Sciences, through the Awards to Scholarly Publications Program, using funds provided by the Social Sciences and Humanities Research Council of Canada.

University of Toronto Press acknowledges the financial support of the Government of Canada through the Canada Book Fund for its publishing activities. 
For Geraldine Elizabeth Clarke 2939-2000

For William Lloyd Clarke 2935-2005 
This page intentionally left blank 
The true, the good and the beautiful always exist by contrast with the false, the evil and the ugly, and grow in struggle with the latter.

Mao Zedong, Four Essays on Philosophy

I want beauty to be me.

Jael Ealey, 'My Upside-Down Black Face' 
This page intentionally left blank 